\title{
Multifunctional Spirocyclic Systems
}

\section{Boris Lukyanov, ${ }^{1}$ Gennadii Vasilyuk, ${ }^{2}$ Eugene Mukhanov, ${ }^{1}$ Leonid Ageev, ${ }^{3}$ Maria Lukyanova, ${ }^{1}$ Yury Alexeenko, ${ }^{4}$ Serguei Besugliy, ${ }^{4}$ and Valeri Tkachev ${ }^{5}$}

\footnotetext{
${ }^{1}$ Institute of Physical and Organic Chemistry, Southern Federal University, Rostov-on-Don 344090, Russia

${ }^{2}$ Physical engineering department, Yanka Kupala State University, Grodno, 230023 Belorussia, Belarus

${ }^{3}$ Physical department, V. Karazin Kharkiv National University, Kharkiv 61077, Ukraine

${ }^{4}$ Southern Scientific Center, Russian Academy of Sciences, Rostov-on-Don 344006, Russia

${ }^{5}$ Institute of Problems of Chemical Physics, Russian Academy of Science, Chernogolovka 142432, Russia
}

Correspondence should be addressed to Boris Lukyanov, bluk@ipoc.rsu.ru

Received 26 March 2009; Revised 17 August 2009; Accepted 18 October 2009

Recommended by Mohamed Sabry Abdel-Mottaleb

\begin{abstract}
New spiropyrans with different substituents in the benzopyran fragment have been synthesized and investigated. It was shown that introduction of aldehyde group in the structure of spiropyrans gives a possibility to obtain new functionalized compounds. Effects of the substituents on the photochromic behavior were studied.
\end{abstract}

Copyright ( $) 2009$ Boris Lukyanov et al. This is an open access article distributed under the Creative Commons Attribution License, which permits unrestricted use, distribution, and reproduction in any medium, provided the original work is properly cited.

\section{Introduction}

Photochromic compounds based on spiropyrans as well as $[2 \mathrm{H}]$-chromenes are perspective photosensitive materials for molecular switches, optical filters with modulated transmission, and hybrid multifunctional materials. Conceptual aspects of a spiropyran practical application are based on photo-, thermo-, solvate-, and electrochromic properties [1].

Spiropyrans are applicable for using in molecular logic devices, photochromic and electrooptical devices [2], and multifunctional artificial receptors [3]. Photochromic spiropyrans can be used for creation of various types of optical memory [4] in quantum computers.

Reactions of different functional groups give an opportunity to obtain compounds with a variety of untraditional $\pi$-acceptor substituents, which can dramatically change spiropyran properties. Synthesis of the differently substituted spiropyrans and results of these structural modifications will be discussed in this work.

\section{Results and Discussion}

Previously we synthesized and studied number of spiropyrans of benzoxazinone and indoline series [5]. We decided to continue our research of aldehyde-substituted spirocompounds.

8' -Formyl-3,6' -dimethyl-4-oxo-3,4-dihydrospiro-2H-1, 3-benzoxazine- $2,2^{\prime}-[2 \mathrm{H}]$ chromene $4 \mathbf{a}$ was synthesized by the reaction of benzoxazinonium perchlorate 1 with 2,6diformyl-4-methyl-phenol 2 followed by cyclization of obtained merocyanine salt 3 .<smiles></smiles><smiles>Cc1cc(C=O)c(O)c(C=O)c1</smiles><smiles>Cc1cc(C=O)c2c(c1)C=CC1(Oc3ccccc3C(=O)N1C)O2</smiles>

$4 \mathrm{a}$ 
Reactivity of the aldehyde group in the benzopyran part allows to obtain derivatives figures $4 \mathrm{~b}, \mathrm{c}$ containing azomethine and hydrazine fragment as a result of the reaction with amines and hydrazines correspondingly [6]. Multifunctional spirocyclic compounds and derivatives of spiropyrans possessing the ability to form mono- and binucluear complexes with transition metals could attract great interest due to their potential application as active light-sensitive components of the organic and composite nanostructures.<smiles>Cc1cc2c(c(/C=N\c3ccccc3O)c1)OC1(C=C2)Oc2ccccc2C(=O)N1C</smiles>

$4 b$<smiles>Cc1cc2c(c(/C=N/NC(=O)c3ccccc3)c1)OC1(C=C2)Oc2ccccc2C(=O)N1C</smiles>

$4 \mathrm{c}$
Spirocompound $4 \mathbf{d}$ with the benzocrown- 5 fragment was synthesized [7]. The benzocrown-5 fragment in $\mathbf{4 d}$ was connected to the $[2 \mathrm{H}]$-chromene part through a conjugated $\pi$ electron-withdrawing $\mathrm{C}=\mathrm{N}$ bond to prolong the conjugation chain in the open colored form. This structure is able to potential selective binding of metal ions.<smiles>Cc1cc2c(c(/C=N/c3ccc4c(c3)OCCOCCOCCOCCO4)c1)OC1(C=C2)Oc2ccccc2C(=O)N1C</smiles>

The complex formed by capture of metal ion in the crown-ether cavity could be an original $\pi$-acceptor substituent. Additional $\pi$-acceptor nitrosubstituent could turn on the photochromic properties in spiropyrans containing azomethyne substituents [8].

Spiropyran 5 was synthesized by condensation of the 1,2,3,3-tetramethylindolenilium salt with the 2,4-diformyl6-methyl phenol. New compound $\mathbf{5 a}$ was obtained after condensation with the para-methoxy-phenoxyacetic acid hydrazide 6 .<smiles>CCCCC1(C)c2ccccc2N(C)C12C=Cc1cc(/C=N/NC(=O)C(=O)OCc3ccc(OC)cc3)cc(C)c1O2</smiles>

Presence of the chelating hydrazide fragment in the structure $\mathbf{5} \mathbf{a}$ allowed to expect a complex compound formation with metal ions. It was shown that methoxy- and methyl- substituents in the benzopyran part of compound $\mathbf{5 a}$ increase solubility and permit to carry out a detailed study of the obtained complex properties. In addition, the unshared electronic pairs of the methoxy group oxygen atom could expand the possibilities of complexation.

Also new aldehyde-substituted spiropyran 7 was synthesized by condensation of the 1,2,3,3-tetramethylindolenilium salt with corresponding aldehyde.

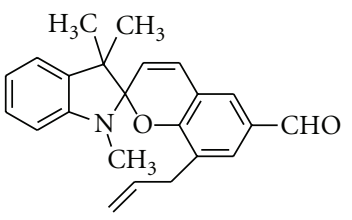

7

\section{Photochromic Properties}

Spiropyran 4a containing $\pi$-acceptor substituent possesses photochromic properties in solid state as well as in solution [9]. Thin films of spiropyran $4 \mathbf{a}$, which were prepared by thermal vacuum deposition on glass and quartz supports, turned colored under UV irradiation at $\lambda_{\max }=365 \mathrm{~nm}$. The resulting colored form is characterized by absorption in the visible region with $\lambda_{\max }=605 \mathrm{~nm}$ and the lifetime of 1 hour (Figure 1).

Spiropyrans $4 \mathbf{b}, \mathrm{c}$ do not exhibit photochromic properties. Such behavior could be explained by the fact that modification of the 8 -aldehyde group substantially reduced the electron-accepting effect of this group. Consequently it reduces the polarity of the $\mathrm{C}_{\text {spiro }}-\mathrm{O}$ bond and negatively affects on photochromic properties of the compounds.

It was shown that obtaining of the colored merocyanine products $\mathbf{4 d}$ does not occur under irradiation with UV-light $(365 \mathrm{~nm})$. Only reversible E-Z isomerization was observed under the experimental condition. The complex formed 


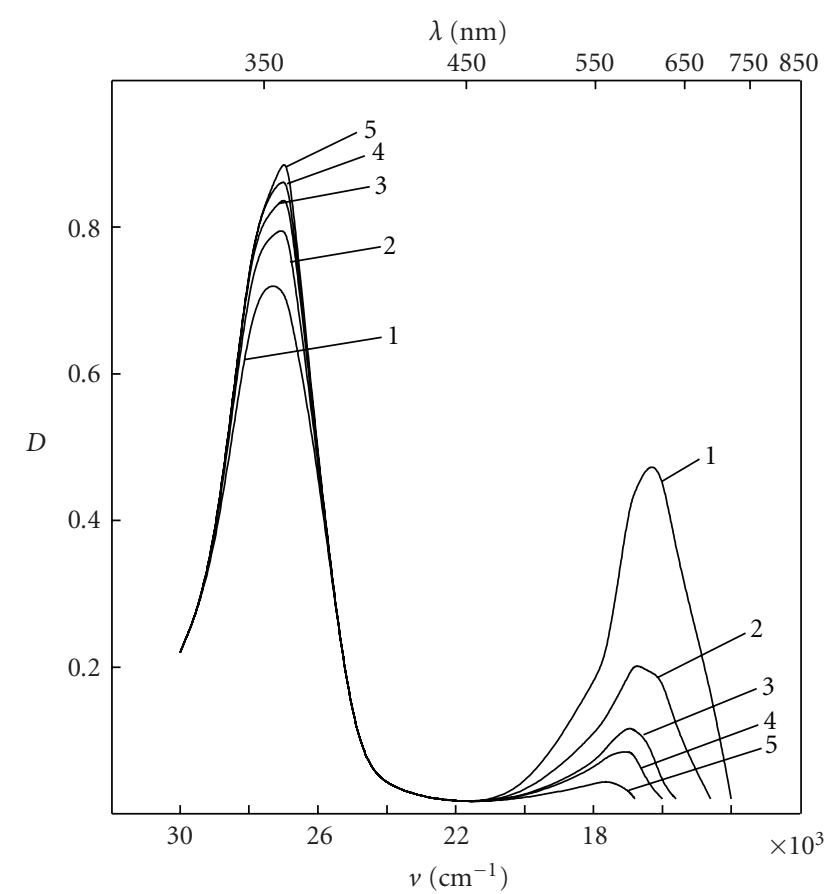

FIgURE 1: Electronic absorption spectra of the irradiated film of spiropyran $4 \mathrm{a}: 1$, the irradiated form (reverse dark reaction). Time after irradiation/min: 2, 5; 3, 15; 4, 30; 5, 60 .

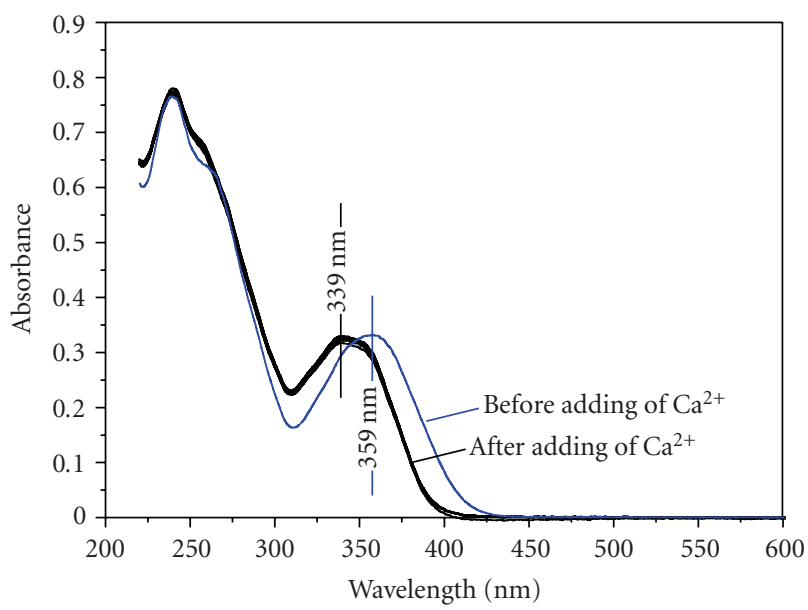

Figure 2: Changes in the absorption spectra of $\mathbf{4} \mathbf{d}$ solution after adding of calcium ions.

by possible capture of a metal ion by the crown ether cavity may be a unique additional electron-withdrawing substituent, which activates photochromic properties in spiropyrans containing an azomethine substituent. Adding of the lithium ions to the solution of $\mathbf{4 d}$ does not lead to the breaking of $\mathrm{C}_{\text {spiro }}-\mathrm{O}$ bond in contrast to the spiropyrans of indoline series. However, hypsochromic shift of the absorption maxima $(20 \mathrm{~nm})$ was observed after adding of the calcium ions to the solution of $\mathbf{4 d}$. This fact was explained by the interaction between cyclic spiroform $4 \mathbf{d}$ and $\mathrm{Ca}^{2+}$ ions (Figure 2).

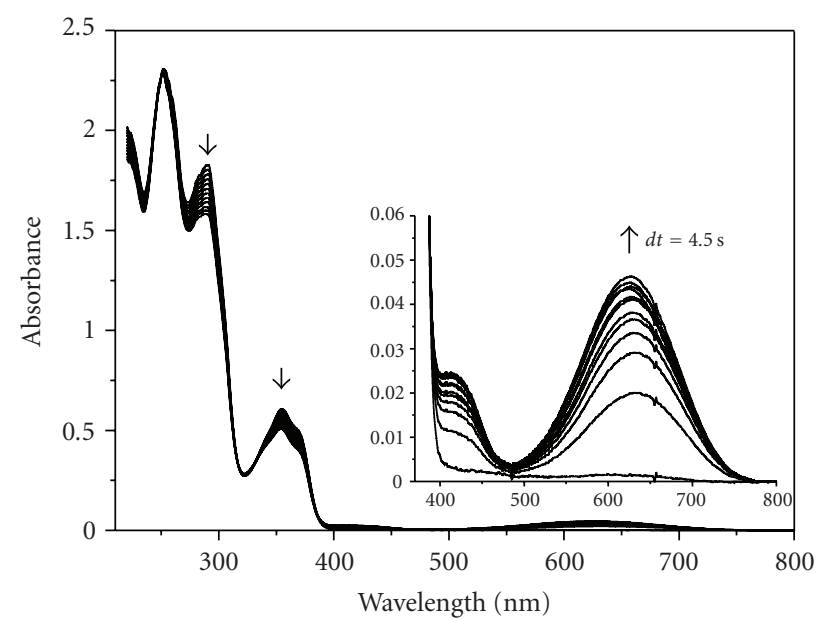

Figure 3: Absorption spectra of the compound $\mathbf{5 a}$ in acetonitrile $\left(C=6,43 \times 10^{-5} \mathrm{M}, T=30^{\circ} \mathrm{C}\right)$ under irradiation in stationary conditions by light $\lambda_{\max } 365 \mathrm{~nm}$.<smiles>Cc1cc2c(c(/C=N/c3ccc4c(c3)OCCOCCOCCOCCO4)c1)OC1(C=C2)Oc2ccccc2C(=O)N1C</smiles>

Spiropyran 5a undergoes reversible photochromic transformations and new long-wave maxima appears at the $630 \mathrm{~nm}$ under irradiation of the UV-light with the $\lambda=$ $365 \mathrm{~nm}$ in stationary conditions.

The system behavior in UV spectral region is essentially different for photo- (Figure 3 ) and back thermal reaction (Figure 4). Effective route for irreversible process could be the reason of such properties. Changing of the long-wave absorption band form is observed during back thermal reaction that could be explained by obtaining of several cistrans merocyanine isomers.

This compound is a potential chemosensor due to its possibility to capture metal ions by chelating hydrazone fragment. This process could be interesting for using in active light-sensitive element of nanostructural materials.

Addition of the zinc salt to the compound $\mathbf{5 a}$ acetonitrile solution results in strong coloration and change of the spectrum (Figure 5). Irradiation of the solution with the light $546 / 365 \mathrm{~nm}$ does not lead to any changes in the absorption spectra. This photochromic behavior could be the evidence of the $\mathrm{C}_{\text {spiro }}-\mathrm{O}$ bond breaking and consequent involving of the oxygen atom into complex formation with metal ion that dramatically stabilizes merocyanine isomer. Obtained spectrum is probably the superposition of the different complex compound spectra. 


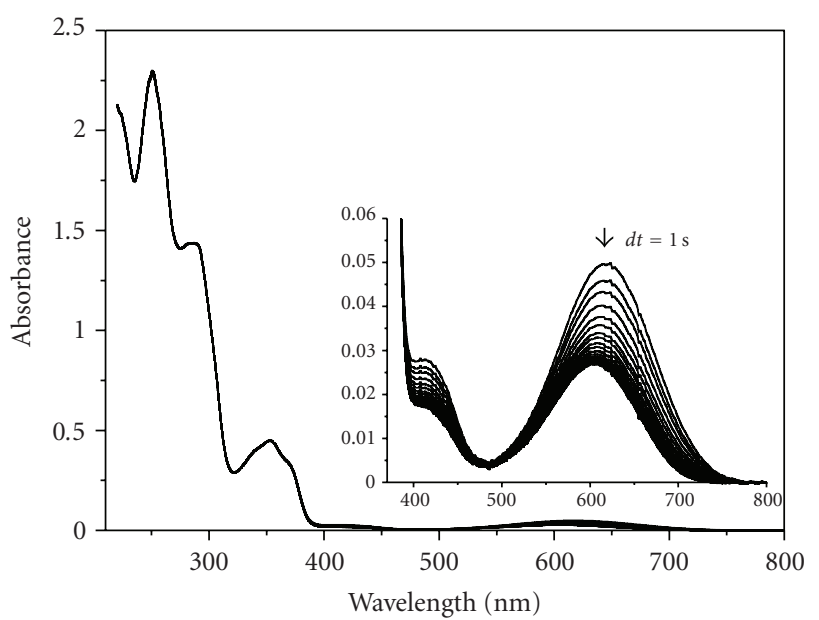

FIGURE 4: Change in the absorbance spectra of the compound $\mathbf{5 a}$ in acetonitrile $\left(C=6,43 \times 10^{-5} \mathrm{M}, T=30^{\circ} \mathrm{C}\right)$ after irradiation (back thermal reaction).

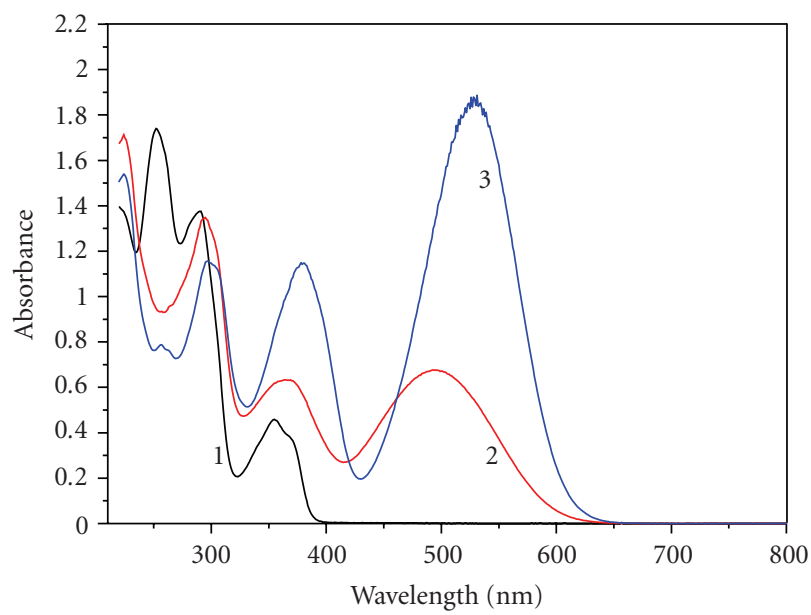

FIgURE 5: Absorption spectra of the compound 5a in acetonitrile $\left(C=4,82 \times 10^{-5} \mathrm{M}, T=30^{\circ} \mathrm{C}\right)$ before (1), immediately after (2) and 20 seconds after $(3)$ addition of zinc salt $\left(\left[\mathrm{Zn}^{++}\right]=1,12 \times 10^{-3}\right)$.

Photochromic properties of compound 7 implanted at the oligocarbonatedimethylacrylate film were investigated. Absorption spectrum of the spiropyran 7 in the stationary conditions is represented on Figure 6. Open merocyanine isomer is produced under irradiation of the polymer film of compound 7 that leads to the appearance of absorption maxima at the $585 \mathrm{~nm}$.

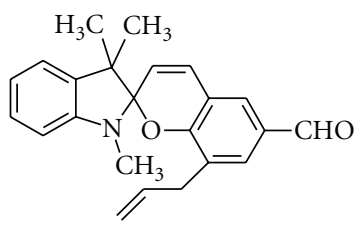

8

It is proposed to use photochromic compounds containing polymerized substituent in the structure as

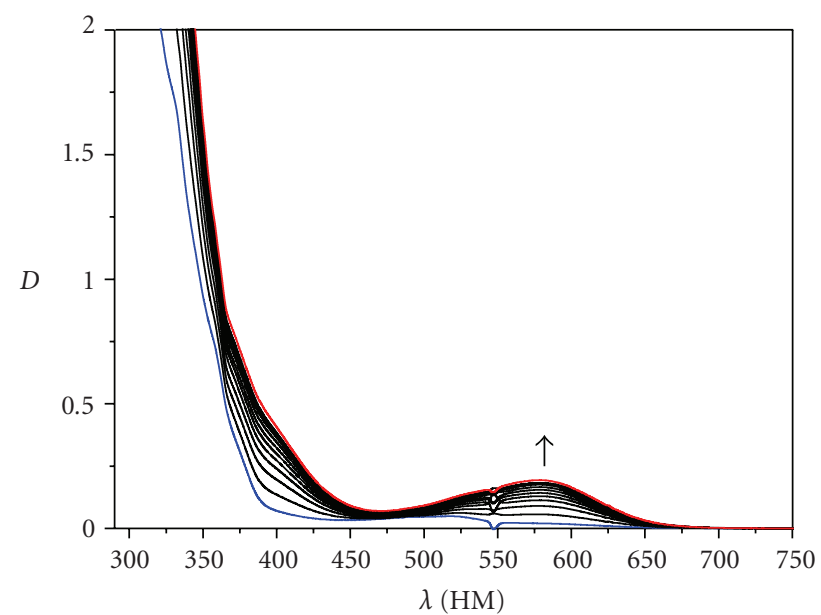

Figure 6: Absorption spectra of the spiropyran 7 in the oligocarbonatedimethylacrylate film during the photocoloration process $\left(\lambda_{\text {irr }}=365 \mathrm{~nm} ; d t=10 \mathrm{~s} ; T=20^{\circ} \mathrm{C}\right)$.

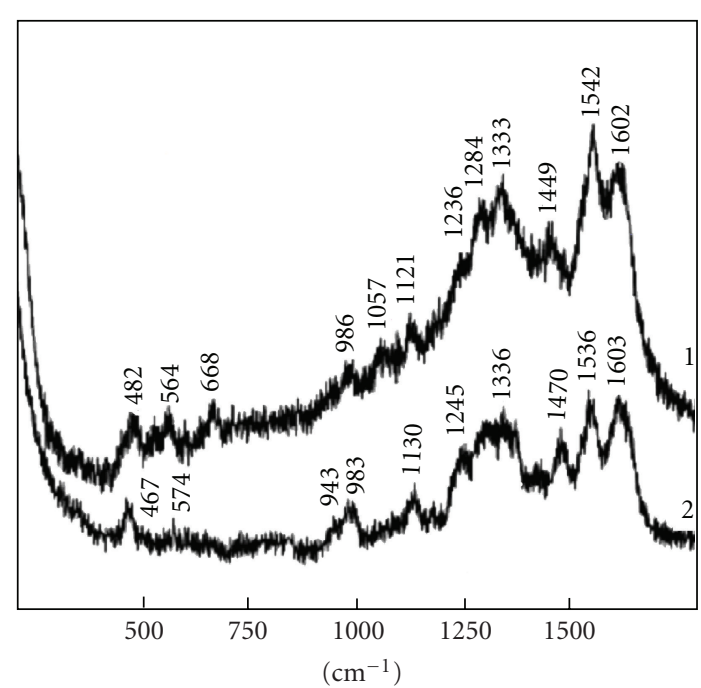

FIGURE 7: The SERS spectra $(\lambda \operatorname{exc}=514.5 \mathrm{~nm})$ of compound $\mathbf{5 a}$ adsorbed on the annealed (1) and unannealed (2) silver films.

photochromic component in development of the nextgeneration intraocular lenses. These devices are very important due to the physiologically proved strategy of the retina protection and essential reduction of quantity of the short wave light reaching a retina and pigmentary epithelium.

\section{SERS and AFM Investigations}

Study of the structure and photophysical properties of photochromes in an adsorbed state is of great importance for practical applications. One of the most efficient methods applied to investigate adsorbates is the spectroscopy of surface enhanced Raman scattering (SERS) [10]. Structure of the compound $\mathbf{5} \mathbf{a}$ adsorbed on the annealed and unannealed silver films was investigated (Figure 7). 

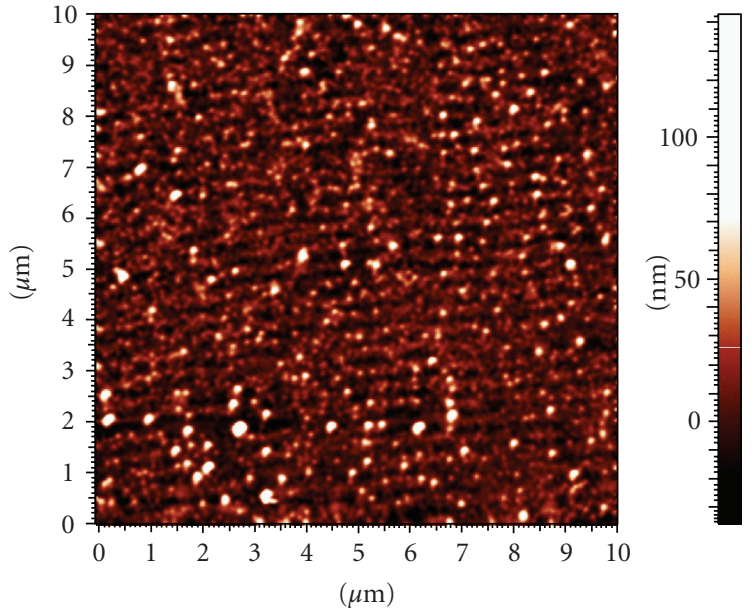

FIGURE 8: AFM-images of the photosensitive layer based on the optically attained (3 minutes) nanostructured AgCl-Ag.

In the SERS spectra the typical band of the colorless spiropyran form at about $1640 \mathrm{~cm}^{-1}$ is absent [11]. Consequently, in our experiments with application of the SERS spectroscopy only the colored (with an open pyran cycle) form of the spiropyran molecules is detected. The equilibrium between the colorless and colored forms is shifted to the merocyanine on the silver surface. The photochromism in investigated solutions is manifested only with apparently low quantum yields and very small concentration of the open form. The dissociation of the adsorbed molecules, that is, the opening of the pyran ring at the adsorbed state can be associated with the fact that the energy of $\mathrm{C}_{\text {spiro }}-\mathrm{O}$ bond decreases because of the spiro-oxygen interaction with the sorbent surface.

Using of the light-sensitive layers containing nanostructured colloid argentums (like AgCI-Ag) in the capacity of SERS-active substrates could give additional amplification of the SERS signal. Thin photosensitive layers of AgCIAg had been produced by the thermal vacuum deposition on the glass and quartz surfaces. Absorption spectra and AFM-images of the thin films were taken. The aggregate of the $\mathrm{Ag}$ granules with vertical dimensions $5 \cdots 40 \mathrm{~nm}$ and horizontal dimensions $50 \cdots 100 \mathrm{~nm}$ (Figure 8) acts like colloid and determines resonant absorption of the light in the AgCI-Ag films. Maximum of the colloidal absorption band for the AgCI-Ag films is located at the $530 \mathrm{~nm}$ (Figure 9).

\section{Experimental}

The electronic spectra of the investigated compounds were recorded at room temperature on a Varian Carry spectrometer. The absorption spectra before and after irradiation were recorded on a Specord UV-Vis spectrometer fitted with a special cryostat for low-temperature measurements. The excitation source was a DRSh-250 mercury lamp with light filters isolating light with $\lambda_{\max } 313$ and $365 \mathrm{~nm}$.

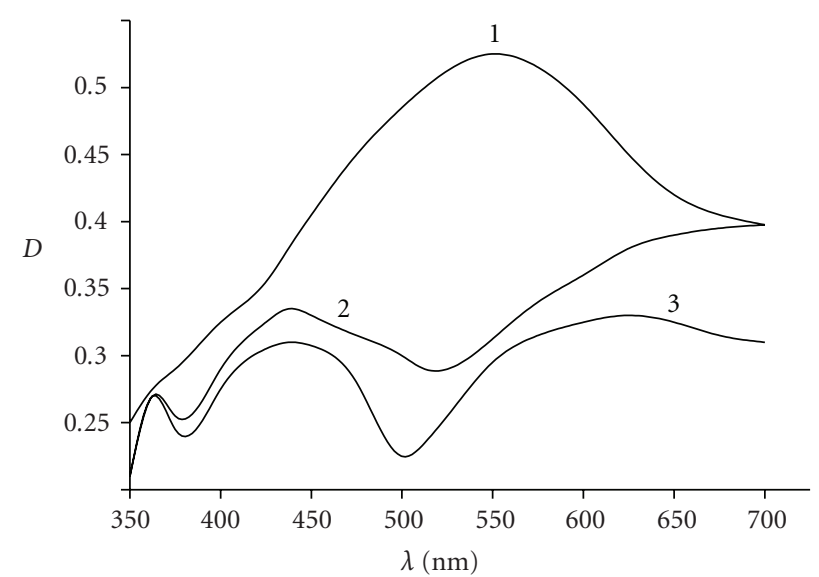

FIGURE 9: Absorption spectra of the the optically attained nanostructured AgCl-Ag: 1 minute before exposition; 2-3 minutes of exposition; 3-5 minutes of exposition by laser $514 \mathrm{~nm}, 30 \mathrm{~mW}$.

5.1. 8'-Formyl-3,6-dimethyl-4-oxo-3,4-dihydrospiro-2H-1,3benzoxazine-2,2' $-[2 \mathrm{H}]$ chromene $\mathbf{4 a}$. Compound $\mathbf{4 a}$ was prepared from benzoxazinonium perchlorate 1 with 2,6diformyl-4-methyl-phenol 2 by a procedure described previously [12]. Yield-22 \%. M.p. $146^{\circ} \mathrm{C}(\mathrm{EtOH})$. Found (\%): C, 71.07; H, 4.64; N, 4.54. $\mathrm{C}_{19} \mathrm{H}_{15} \mathrm{NO}_{3}$. Calculated (\%): C, 71.02; H, 4.70; N, 4.36. IR, $v / \mathrm{cm}^{-1}: 1670(\mathrm{C}=\mathrm{O}) ; 1638,1610$, $1582(\mathrm{C}=\mathrm{C}) ; 958,936(\mathrm{C}-\mathrm{O}) .{ }^{1} \mathrm{H}$ NMR $(\mathrm{CDCl} 3), \delta: 2.33$ (s, /3 H, 6'-Me); 3.04 (s, $3 \mathrm{H}, \mathrm{N}-\mathrm{Me}) ; 6.00\left(\mathrm{~d}, 1 \mathrm{H}, 3^{\prime}-\mathrm{H}\right.$, $J=12.5 \mathrm{~Hz}) ; 6.30-8.13(\mathrm{~m}, 7 \mathrm{H}) ; 9.75\left(\mathrm{~s}, 1 \mathrm{H}, 8^{\prime}-\mathrm{CHO}\right)$.

5.2. 8' -(3-Iminobenzo-15-crown-5)-3,6'-dimethyl-4-oxo-3,4dihydrospiro(2H-1,3-benzoxazine-2,2'-[2H]-chromene) 4 d. 4-Aminobenzo-15-crown-5 $(0.09 \mathrm{~g}, 0.031 \mathrm{mmol})$ was added to a solution of $8^{\prime}$-formyl-3, $6^{\prime}$-dimethyl-4-oxo-3,4-dihydrospiro(2H-1,3-benzoxazine-2,2-[2H]-chromene) 4a (0.1 g, $0.3 \mathrm{mmol})$ in ethanol $(3 \mathrm{ml})$ at reflux. The solution was heated at reflux for 30 minutes. The solvent was distilled off in vacuum and the residue obtained was recrystallized from ethanol to give $0.15 \mathrm{~g}(81 \%)$ 4d. M.p $153-154^{\circ} \mathrm{C}$. Found, \%: C 67.42; H 5.93; N 4.65. $\mathrm{C}_{33} \mathrm{H}_{34} \mathrm{~N}_{2} \mathrm{O}_{6}$. Calculated, \%: C 67.56; H 5.84; N 4.78. IR, $v / \mathrm{cm}^{-1}: 1680(\mathrm{C}=\mathrm{N}), 1642(\mathrm{C}=\mathrm{O})$, 1617, $1578(\mathrm{C}=\mathrm{C}), 1264(\mathrm{C}-\mathrm{N}), 1148,974,952(\mathrm{C}-\mathrm{O})$. ${ }^{1} \mathrm{H}$ NMR $\left(\mathrm{CDCl}_{3}\right), \delta$, ppm $(J, \mathrm{~Hz}): 2.35\left(1 \mathrm{H}, \mathrm{s}, \mathrm{CH}_{3}\right) ; 3.19$ $\left(1 \mathrm{H}, \mathrm{s}, \mathrm{N}-\mathrm{CH}_{3}\right) ; 3.64-4.18\left(16 \mathrm{H}, \mathrm{m}, \mathrm{O}-\mathrm{CH}_{2}-\mathrm{CH}_{2}-\mathrm{O}\right) ; 6.12$ $\left(1 \mathrm{H}, \mathrm{d}, J=9.7, \mathrm{H}-3^{\prime}\right) ; 6.39\left(1 \mathrm{H}, \mathrm{dd}, J=8.5, J=2.3, \mathrm{H}-5^{\prime \prime}\right)$; $6.54\left(1 \mathrm{H}, \mathrm{d}, J=2.3, \mathrm{H}-3^{\prime \prime}\right) ; 6.74\left(1 \mathrm{H}, \mathrm{d}, J=8.5, \mathrm{H}-6^{\prime \prime}\right)$; $6.84(1 \mathrm{H}, \mathrm{d}, J=8.0, \mathrm{H}-8) ; 7.00\left(1 \mathrm{H}, \mathrm{d}, J=9.7, \mathrm{H}-4^{\prime}\right)$; 7.10-7.20 (2H, m, H-6, H-5'); $7.43(1 \mathrm{H}, \mathrm{m}, \mathrm{H}-7) ; 7.86(1 \mathrm{H}$, $\left.\mathrm{m}, \mathrm{H}-7^{\prime}\right) ; 8.04(1 \mathrm{H}, \mathrm{d}, J=7.8, \mathrm{H}-5) ; 8.26(1 \mathrm{H}, \mathrm{s}, \mathrm{N}=\mathrm{CH})$.

5.3. Spiropyran 5a. To para-methoxy-phenoxyacetic acid hydrazide $\mathbf{6}(1.96 \mathrm{~g}, 0.01 \mathrm{~mol})$ in benzene $(10 \mathrm{ml})$ we added an equivalent amount of the spiropyran $5(3.19 \mathrm{~g}, 0.01 \mathrm{~mol})$. The mixture was refluxed for 1 hour and allowed to stand until a precipitate had separated. The precipitate was filtered off, dried, and recrystallized from ethanol. Yield $2.8 \mathrm{~g}$ (56\%). M.p. $194-196^{\circ} \mathrm{C}$. 
Found, \%: C 72.51; $\mathrm{H}$ 6.22; $\mathrm{N}$ 8.40. $\mathrm{C}_{30} \mathrm{H}_{31} \mathrm{~N}_{3} \mathrm{O}_{4}$. Calculated, \%: C 72.43; H 6.24; N 8.45. IR, $v / \mathrm{cm}^{-1}$ : 1673 $(\mathrm{C}=\mathrm{N}), 1639(\mathrm{C}=\mathrm{O}), 1610,1583,1572(\mathrm{C}=\mathrm{C}), 1259(\mathrm{C}-\mathrm{N})$, $1135,961,952(\mathrm{C}-\mathrm{O})$.

${ }^{1} \mathrm{H}$ NMR $\left(\mathrm{CDCl}_{3}\right), \delta$, ppm. $(J, \mathrm{~Hz}): 1.19,1.30(6 \mathrm{H}, 2-\mathrm{s}$, gem. $\left.\left(\mathrm{CH}_{3}\right)_{2}\right) ; 2.25\left(3 \mathrm{H}, \mathrm{s}, 8^{\prime}-\mathrm{CH}_{3}\right) ; 2,78\left(3 \mathrm{H}, \mathrm{s}, \mathrm{N}-\mathrm{CH}_{3}\right)$; $3.8\left(3 \mathrm{H}, \mathrm{s}, \mathrm{O}-\mathrm{CH}_{3}\right) ; 4.58\left(2 \mathrm{H}, \mathrm{c},-\mathrm{CH}_{2}-\right) ; 5.7(1 \mathrm{H}, \mathrm{d}, J=$ $8.5)$; 6.52-7.8 (11 H, m, aromatic $\mathrm{H}) ; 8.06(1 \mathrm{H}, \mathrm{s}, \mathrm{N}=\mathrm{CH})$; 9.4 (1 H, s, -NH-).

5.4. 6' -Formyl-8' -allyl-1,3,3-trimethylspiroindoline-2,2' - $[2 \mathrm{H}]$ chromene 7. Piperidine $(0.1 \mathrm{ml}, 1.1 \mathrm{mmol})$ was added dropwise with heating to a solution of 2,4-diformyl-6-allylphenol (189 mg, $1 \mathrm{mmol}$ ) and 1,2,3,3-tetramethylindolenium perchlorate $(274 \mathrm{mg}, 1 \mathrm{mmol})$ in 2-propanol $(5 \mathrm{ml})$. The reaction mixture was refluxed for 10 minutes and cooled. The precipitate was filtered off and recrystallized. M.p. $84^{\circ} \mathrm{C}$. Found, \%: C 79,99; $\mathrm{H} 6,62 ; \mathrm{N} 4,11 . \mathrm{C}_{23} \mathrm{H}_{23} \mathrm{NO}_{2}$. Calculated, \%: C 80,00; H 6,67; N 4,06. IR, $v / \mathrm{cm}^{-1}$ : 1675 (C=O), 1630, $1590(\mathrm{C}=\mathrm{C}), 1010,920(\mathrm{C}-\mathrm{O}) .{ }^{1} \mathrm{H} \mathrm{NMR}\left(\mathrm{CDCl}_{3}\right), \delta, \mathrm{ppm}$ $(J, \mathrm{~Hz}): 1.21,1.32\left(6 \mathrm{H}, 2-\mathrm{s}\right.$, gem. $\left.\left(\mathrm{CH}_{3}\right)_{2}\right) ; 2.66(3 \mathrm{H}, \mathrm{s}, \mathrm{N}-$ $\left.\mathrm{CH}_{3}\right) ; 3.07-3.20\left(2 \mathrm{H}, \mathrm{m},=\mathrm{CH}_{2}\right) ; 4.70-4.91\left(2 \mathrm{H}, \mathrm{m},-\mathrm{CH}_{2}-\right.$ ); 5.64-5.82 (1 H, m, =CH-); $5.77\left(1 \mathrm{H}, \mathrm{d}, J=9,6,3^{\prime}-\mathrm{H}\right)$; $6.53\left(1 \mathrm{H}, \mathrm{d}, J=7,7,4^{\prime}-\mathrm{H}\right) ; 6.84-7.57(6 \mathrm{H}, \mathrm{m}$, aromatic $\mathrm{H})$; $9.81(1 \mathrm{H}, \mathrm{s}, \mathrm{CHO})$.

\section{Conclusion}

New differently substituted spirocompounds were synthesized on the basis of formyl-containing spiropyrans of benzoxazine and indoline series. Structure and photochromic properties of obtained compounds were investigated in solution and in thin solid films.

\section{Acknowledgments}

This work was financial supported by Russian Foundation for Basic Research (Grants 07-03-00234, 08-03-90029-Bel), Belarusian Republic Foundation for Basic Research (Grant F08R-228) as well as the Grant of the Russian Federation President NSh-363.2008.3., Russian-American program BRHE, and the Ministry of Education and Science of Russian Federation (project RNP.2.2.2.3.16011, RNP 2.2.2.2.3915, BP3C04, BP4M04).

\section{References}

[1] V. I. Minkin, "Photo-, thermo-, solvato-, and electrochromic spiroheterocyclic compounds," Chemical Reviews, vol. 104, no. 5, pp. 2751-2776, 2004.

[2] G. Favaro, G. Chidichimo, P. Formoso, S. Manfredi, U. Mazzucato, and A. Romani, "Chromatic and dynamic characteristics of some photochromes in the components of bifunctional photochromic and electro-optical devices," Journal of Photochemistry and Photobiology A, vol. 140, no. 3, pp. 229-236, 2001.

[3] M. Inouye, "Molecular crystals and liquid crystals science and technology. Section A: molecular crystals and liquid crystals,"
Molecular Crystals and Liquid Crystals, vol. 246, pp. 169-172, 1994.

[4] M. A. Suzuki, T. Hashida, J. Hibino, and Y. Kishimoto, "Multiple optical memory using photochromic spiropyran aggregates," Molecular Crystals and Liquid Crystals, vol. 246, pp. 389-396, 1994.

[5] Yu. S. Alekseenko, B. S. Lukyanov, A. N. Utenyshev, et al., "Photo-and thermochromic spiranes. 24. Novel photochromic spiropyrans from 2,4-dihydroxyisophthalaldehyde," Chemistry of Heterocyclic Compounds, vol. 42, no. 6, pp. 803812, 2006.

[6] A. O. Bulanov, B. B. Safoklov, B. S. Luk'yanov, et al., "Photochromic and thermochromic spiropyrans. 22. Spiropyrans of the 4-Oxo-3,4-dihydro-3H-1,3-benzoxazine series containing $\pi$-accepting substituents at position $8^{\prime}$," Chemistry of Heterocyclic Compounds, vol. 39, no. 3, pp. 315-317, 2003.

[7] M. B. Lukyanova, V. A. Kogan, and B. S. Lukyanov, "A new spiropyran with a cation receptor," Chemistry of Heterocyclic Compounds, vol. 43, no. 11, pp. 1477-1478, 2007.

[8] B. S. Luk'yanov, L. E. Nivorozhkin, and V. I. Minkin, "Photoand thermochromic spirans," Chemistry of Heterocyclic Compounds, vol. 29, no. 2, pp. 152-154, 1993.

[9] B. B. Safoklov, B. S. Luk'yanov, A. O. Bulanov, et al., "Photo... $[2 \mathrm{H}]$ chromene) possessing photochromic properties in the solid phase," Russian Chemical Bulletin, vol. 51, no. 3, pp. 462466, 2002.

[10] R. K. Chang and T. E. Furtak, Eds., Surface Enhanced Raman Scattering, Moscow, Russia, 1984, [Russian translation].

[11] K. Yoda, T. Ohzeki, T. Yuzawa, and H. Takahashi, "Resonance Raman studies of the solvatochromism and acid-base equilibria of $1^{\prime}, 3^{\prime}$, $3^{\prime}$-trimethylspiro-[2H-1-benzopyran-2,2' indoline]," Spectrochimica Acta, vol. 45A, no. 8, pp. 855-862, 1989.

[12] B. S. Luk'yanov, Yu. I. Ryabukhin, G. N. Dorofeenko, L. E. Nivorozhkin, and V. I. Minkin, "Photochromic and thermochromic spirans," Chemistry of Heterocyclic Compounds, vol. 14, no. 2, pp. 122-127, 1978. 


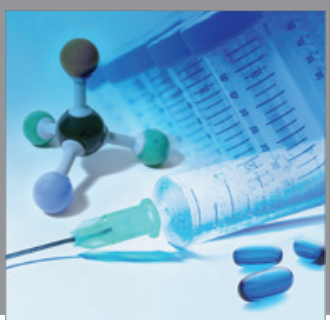

International Journal of

Medicinal Chemistry

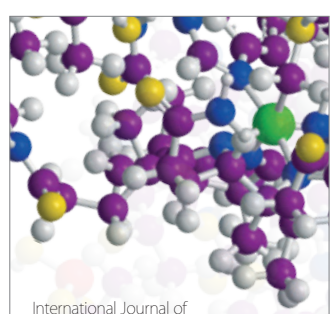

Carbohydrate Chemistry

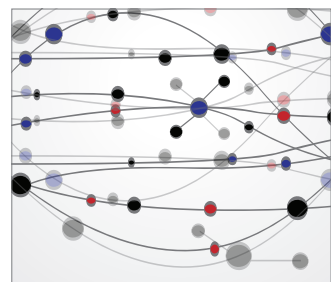

The Scientific World Journal
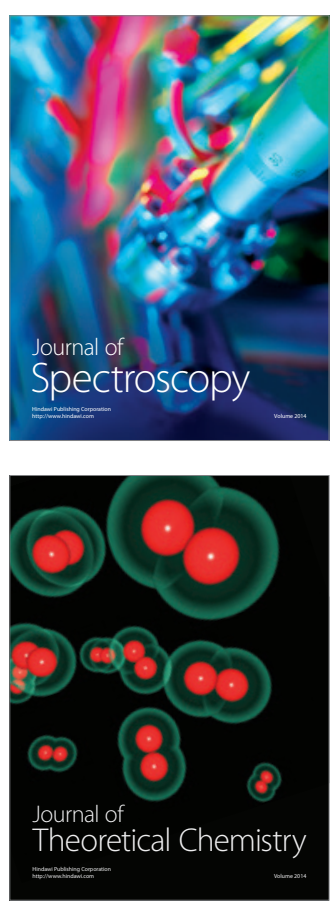
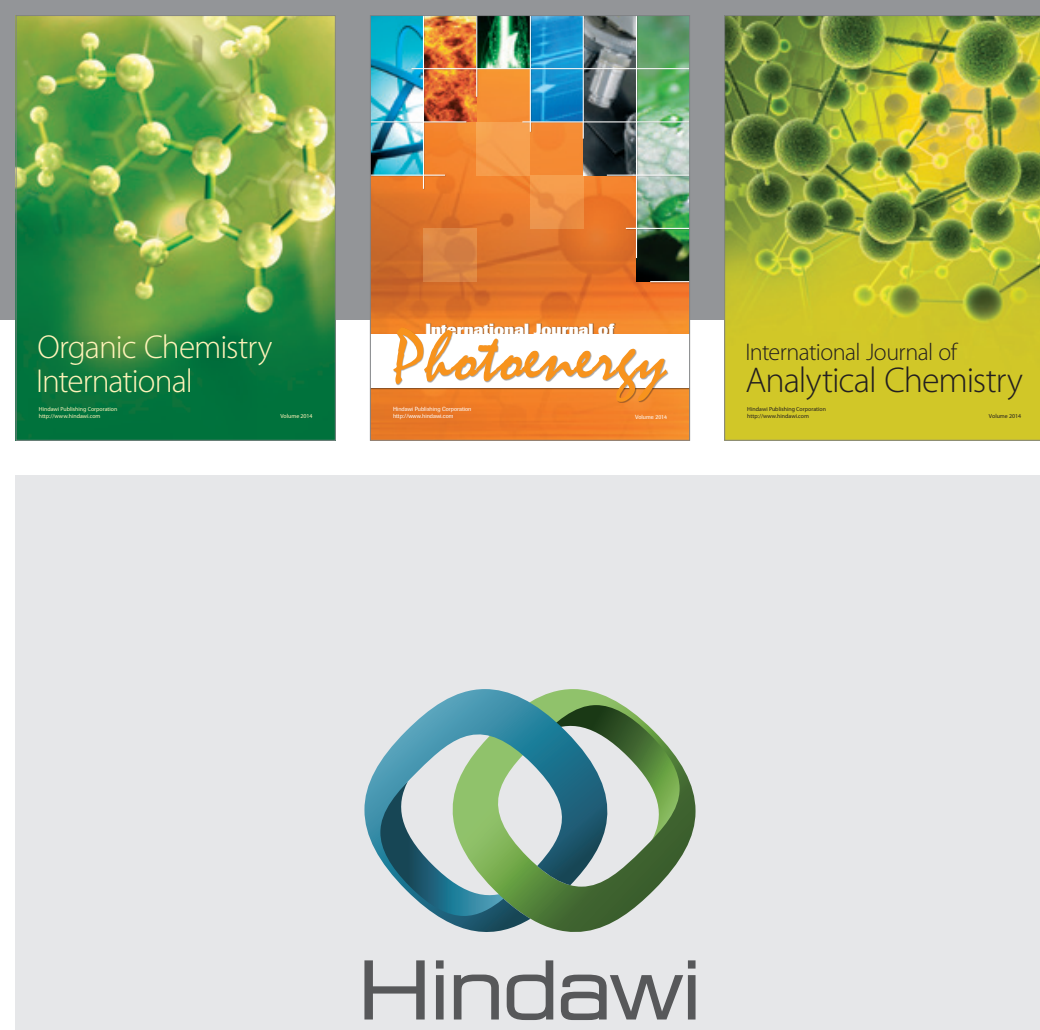

Submit your manuscripts at

http://www.hindawi.com
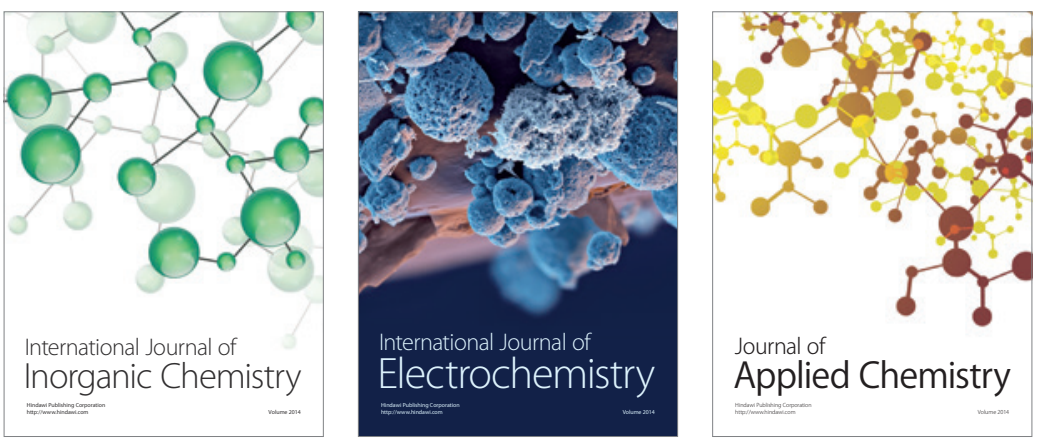

Journal of

Applied Chemistry
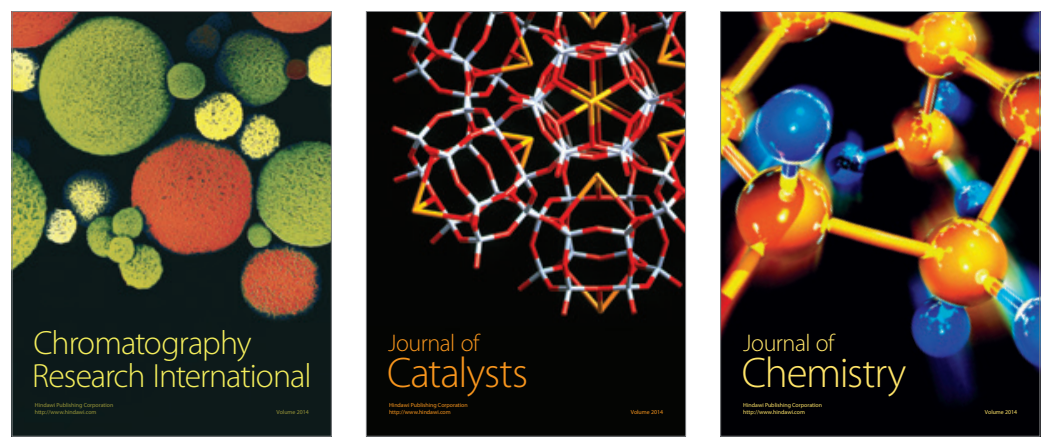
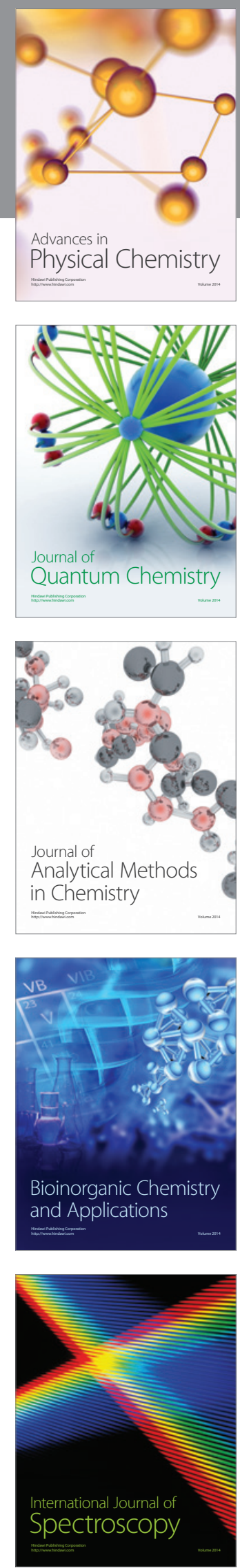